\title{
Analysis of Main Additive Effects and Multiplicative Interactions of Components of Yield of Certain Wheat Genotypes
}

\author{
Nenad Đurić · Mirela Matković · Gorica Cvijanović · Gordana Dozet \\ The John Naisbitt University, Faculty for Biofarming, Maršala Tita 39, 24300 Bačka Topola, Serbia
}

\begin{abstract}
Summary: The effect of genotype, seed category and year on yield components (number of spikelets per spike, grain number per spike, grain weight per spike and thousand grain weight) for three wheat genotypes were studied during a two-year research. Genotype PKB Lepoklasa and seed category prebasic seed had the highest values for the largest number of the studied traits, while the genotype BG Merkur and the certified seed of the first generation had the lowest values. Higher values for the studied traits were found in 2010, compared to 2009. AMMI analysis established a significant effect of the interaction of factors and main components (PCA 1 and PCA 2) for all investigated traits except thousand grain weight. The genotype PKB Talas was the most stable, while the genotype PKB Lepoklasa was the least stable. Seed categories certified seed of the first generation and basic seed had similar reactions to the interaction between factors.
\end{abstract}

Key words: AMMI analysis, genotyping, PCA, seed, wheat, yield components

\section{Introduction}

Wheat yield varies widely due to interactions with the environment. This is a complex hereditary trait, directly or indirectly influenced by several factors (Hristov et al., 2011). Yield depends on the expression of several quantitative traits, as its components (Perišić et al., 2011; Petrović et al., 2013). The creation of a genotype which will have a more superior genetic potential than the existing genotypes is one of the main goals of plant breeding (Dimitrijević \& Petrović, 2005). For this reason, each year wheat breeders must offer producers a new, more productive variety, with higher adaptability and stability than the previously created and widely spread varieties (Mladenov et al., 2005). Stability and adaptability are reactions of genotypes to environmental variations. In agriculture, stability is a desirable reaction of a genotype, which provides a similar level of yield under different environmental conditions via a minor interaction between the genotype and the environment (Dimitrijević et al., 2011). For the most part, the definition of yield is based on the number of spikes per unit area, grain number per spike and grain weight per spike (Golparvar, 2014). However, the expression of these quantitative traits is a consequence of the effect of genes with small effects

Corresponding author: nenad.djuric@outlook.com (minor genes), so that the level of their effect is conditioned by their mutual interaction and the effect of the environment (Perišić et al., 2011).

The development of high yielding cultivars with wide adaptability is the ultimate goal of plant breeders. However, attaining this goal is more complicated by genotype-environment interaction. The additive main effect and multiplicative interaction (AMMI) model proposed by Gauch \& Zobel (1997) proved to be a powerful tool in diagnosting genotype-environment interaction patterns. AMMI method was performed by many researchers working on variety evaluation and stability of wheat (Hintsa et al., 2011; Naroui Rad et al., 2013; Motamedi et al., 2013., Saleem et al., 2015).

Hamlabad (2012) used parametric and nonparametric statistics among the different methods for determination of genotypes with high yield and stability, and found AMMI model to be more effective than the others. Thus, the AMMI model is recommended as the best method to estimate the stability.

Purchase et al. (2000) developed a quantitative stability value to rank genotypes through the AMMI model, namely the AMMI Stability Value (ASV). Mohammed (2009), Farshadfar (2011), Amiri et al. (2013), Hagos \& Abey (2013) used ASV as one method of evaluating grain yield stability of bread wheat varieties.

The main aim of this research was to analyze effect of genotype, seed category and environmental factors 
on components of wheat yield. In addition, the goal is to acquire insight into the stability of investigated genotypes in relation to the interaction of investigated factors.

\section{Materials and Methods}

An experiment using the random block system with three repetitions was set up on the experimental field of Institute PKB Agroekonmomik, Padinska Skela, across $2008 / 2009$ and $2009 / 2010$. The soil type for the experiment was humogley. Standard cultivation practices were applied for wheat production.

Three wheat cultivars were used in this study: PKB Talas, BG Merkur and PKB Lepoklasa, with three treatments related to selection, i.e. with three different seed categories: pre-basic seed, basic seed and certified seed of first generation. Analyzed wheat traits were: number of spikelets per spike, grain number per spike, grain weight per spike and thousand grain weight.

Three-factorial analysis of variance was implemented to obtain insight into the effect of investigated factors on wheat yield components.

In order to achieve a detailed insight into interactions between the genotype and the environment AMMI was implemented. The AMMI model combines the analysis of variance for the genotype and environment main effects with principal components analysis of the genotype $\times$ environment interaction (Zobel et al., 1988; Gauch \& Zobel, 1997).

Purchase et al. (2000) developed the AMMI stability value (ASV) based on the AMMI model's IPCA1 and IPCA2 (interaction principal components axes 1 and 2, respectively) scores for each genotype. ASV was calculated as follows:

$\mathrm{ASV}=\sqrt{\left[\frac{\text { PCA1 sum of square }}{\text { PCA2 sum of square }} \quad(\text { PCA1 score })\right]^{2}+[\text { PCA2 score }]^{2}}$
Statistical data processing was done using the " $\mathrm{R}$ program language" (The R Project for Statistical Computing, version 3.1.3) (R Development Core Team, 2015).

\section{Results and Discussion}

The highest mean value for the number of spikelets per spike was recorded for the genotype PKB Talas (21.66), and it significantly differs from the mean value for the genotype PKB Lepoklasa (21.48) and BG Merkur (21.25). The number of spikelets per spike, together with the harvest index, has a direct effect on grain weight per spike (Zečević et al. 2004).

The seed category pre-basic seed achieved a significantly higher value for the number of spikelets per spike (21.66) compared to categories basic seed (21.6) and certified seed of first generation (21.13). A statistically highly significantly larger number of spikelets per spike was achieved in 2010 (21.82) compared to 2009 (21.11), as shown in Table 1.

According to Aycecik \& Yildirm (2006) the grain number per spike was in positive correlation with grain yield. However, Knežević et al. (2012) indicated that the grain number per spike is a trait to a high extent conditioned by environmental factors which considerably aggravates breeding. The implemented analysis of variance established no statistically significant differences between the studied genotypes, while the average value for grain number per spike was 68.91 (Tab. 1). Seed categories pre-basic seed and basic seed had significantly higher values for grain number per spike (69.91 and 69.84) compared to the certified seed of the first generation (68). The grain number per spike for the studied genotypes and within different seed categories were significantly higher in production year 2010 (71.02) compared to 2009 (67.02), (Tab. 1).

Table 1. Mutual comparison of mean values for the number of spikelets per spike and grain number per spike

\begin{tabular}{llcc}
\hline \multirow{2}{*}{ Factor } & Treatment & Number of spikelets per spike & Grain number per spike \\
\hline \multirow{3}{*}{ Genotype } & BG Merkur & $21.25 \mathrm{c}$ & $68.84 \mathrm{a}$ \\
& PKB Talas & $21.66 \mathrm{a}$ & $68.94 \mathrm{a}$ \\
& PKB Lepoklasa & $21.48 \mathrm{~b}$ & $68.97 \mathrm{a}$ \\
\cline { 2 - 3 } & & $\mathrm{LSD}_{0.01}=0.07 \mathrm{LSD}_{0.05}=0.052$ & $\mathrm{LSD}_{0.01}=0.887 \mathrm{LSD}_{0.05}=0.661$ \\
\hline \multirow{3}{*}{ Seed category } & $21.66 \mathrm{a}$ & $69.91 \mathrm{a}$ \\
& Pre-basic seed & $21.6 \mathrm{~b}$ & $69.84 \mathrm{a}$ \\
& Basic seed & $21.13 \mathrm{c}$ & $68.0 \mathrm{~b}$ \\
\cline { 2 - 3 } & Certified seed of first generation & $\mathrm{LSD}_{0.01}=0.07 \mathrm{LSD}_{0.05}=0.052$ & $\mathrm{LSD}_{0.01}=0.887 \mathrm{LSD}_{0.05}=0.661$ \\
\cline { 2 - 3 } Year & 2009 & $21.11 \mathrm{~b}$ & $67.02 \mathrm{~b}$ \\
\cline { 2 - 3 } & 2010 & $21.82 \mathrm{a}$ & $71.02 \mathrm{a}$ \\
\hline
\end{tabular}

* Different letters within factors indicate statistically significant differences at 5\% statistical level 
Table 2. Analysis of variance of AMMI model for the number of spikelets per spike and grain number per spike

\begin{tabular}{|c|c|c|c|}
\hline Sources of variation & $\begin{array}{c}\text { Degrees of freedom } \\
(\mathrm{df})\end{array}$ & $\begin{array}{l}\text { Number of spikelets per spike } \\
\text { (MS) }\end{array}$ & $\begin{array}{c}\text { Grain number per spike } \\
\text { (MS) }\end{array}$ \\
\hline Treatments (category and year) & 5 & $2.60^{* *}$ & $63.32^{* *}$ \\
\hline Repetitions & 12 & 0.10 & 2.16 \\
\hline Genotype & 2 & $0.76^{* *}$ & 6.21 \\
\hline Genotype* Treatment (category and year) & 10 & $0.72^{* *}$ & $21.57^{* *}$ \\
\hline I PCA 1 & 6 & $0.87 * *$ & $29.62 * *$ \\
\hline I PCA 2 & 4 & $0.50^{* *}$ & $9.49 * *$ \\
\hline Residue & 17 & 0.09 & 2.56 \\
\hline Error & 24 & 4.08 & 91.09 \\
\hline Total & 80 & 4.27 & 95.82 \\
\hline
\end{tabular}

AMMI model analysis of variance for the number of spikelets per spike and grain number per spike was implemented in order to analyze in more detail the interaction, i.e. non additive component of variability (Tab. 2). A detailed analysis of main components shows that the interaction is agronomically significant and that it is defined by two main components (PCA 1 and PCA 2) (Tab. 2). Since no significant difference was found for mean values for grain number per spike under the effect of genotype factors, a detailed AMMI analysis for this trait was left out.

Using the AMMI 1 biplot, a more detailed analysis of interaction for the number of spikelets per spike was carried out. Stability was labeled PCA 1 by a line passing through the value 0 . It is visible that the genotype PKB Talas is the closest to the beginning of the coordinates and that it exhibits the highest stability, i.e. a small effect of the interaction. The following treatments demonstrated stability: certified seed of first generation 2010 and 2009, as well as categories pre-basic seed in 2009 and basic seed in 2010 (Figure 1). Based on this, it can be concluded that the genotype PKB Talas and the mentioned treatments fit well into the additive model, i.e. analysis of variance.

Although the AMMI and GGE biplot (AMMI 2 biplot) gave similar results in identifying superior genotypes, the AMMI 2 biplot was more versatile and flexible, and provided a better understanding (Roostaei et al., 2014).

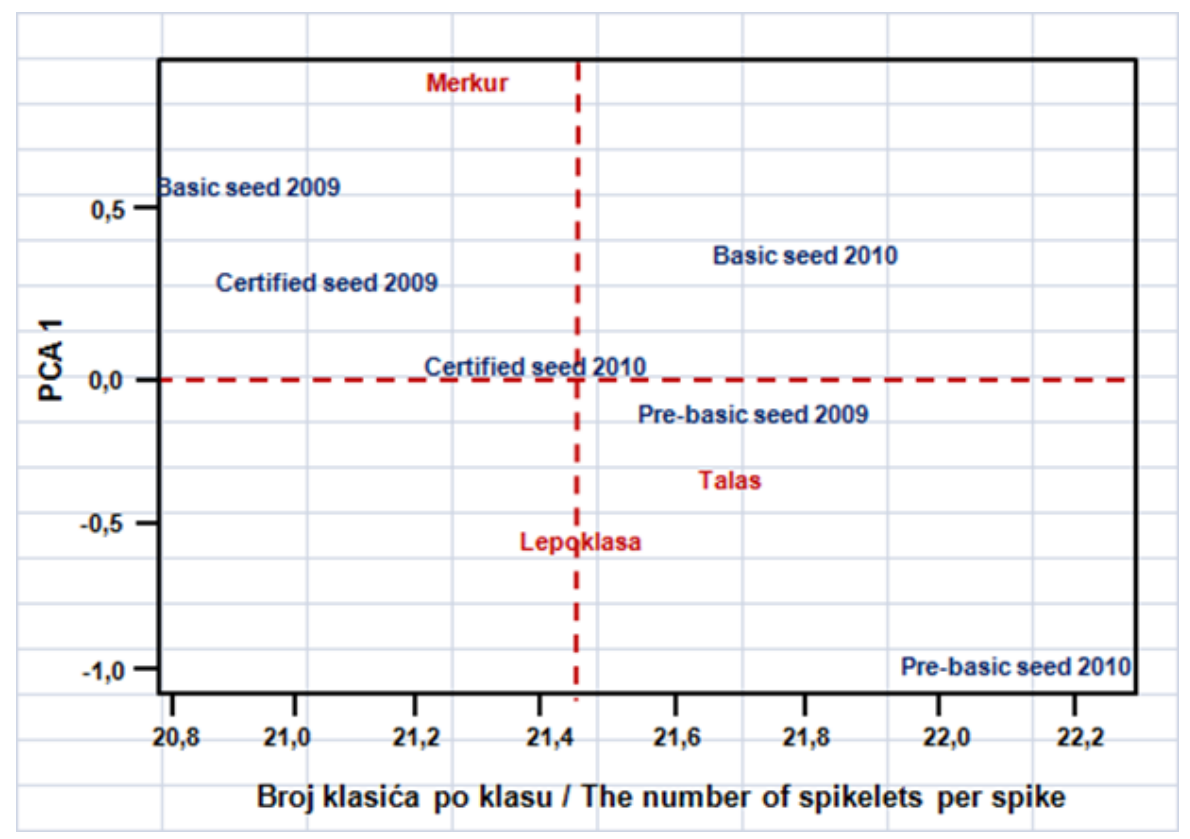

Figure 1. AMMI 1 biplot for the number of spikelets per spike 
The AMMI 2 biplot for the number of spikelets per spike shows that the genotype PKB Talas is more stable compared to the other investigated genotypes. The certified seed of the first generation in 2009 and basic seed in 2009 had the closest vectors, which indicates that they were the most stable and reacted similarly to interaction (Figure 2).

The AMMI model does not provide a quantitative stability measure, such a measure is essential in order to quantify and rank genotypes according to their yield stability, which is why ASV is proposed. ASV is in effect the distance from the coordinate point to the origin in a two-dimensional scattergram of PCA 1 scores against PCA 2 scores. This statistical method can be used to evaluate stability after reduction of noise from the genotype $\times$ environment interaction effects (Amiri et al., 2013).
Genotype PKB Talas, with the least ASV score (1.03), was the most stable, while the genotype BG Merkur (ASV=2.42) showed the most instability (Figure 2).

Investigating yield components of durum wheat (Triticum durum Desf.), Bilgin et al. (2011) established that the highest direct positive effect on yield was present for grain weight per spike. Analyzes genotypes highly significantly statistically differed mutually, with the highest grain weight per spike measured for the genotype PKB Lepoklasa $(3.18 \mathrm{~g})$, and the lowest value registered for the genotype BG Merkur (2.66 g). For grain weight per spike, the seed category pre-basic seed significantly differed (2.92 g) from certified seed of the first generation $(2.84 \mathrm{~g})$. In production year of 2010, a highly significantly higher value for grain weight per spike $(3.03 \mathrm{~g})$ was achieved, compared to the value recorded in 2009 (2.73 g), as shown in Table 3.

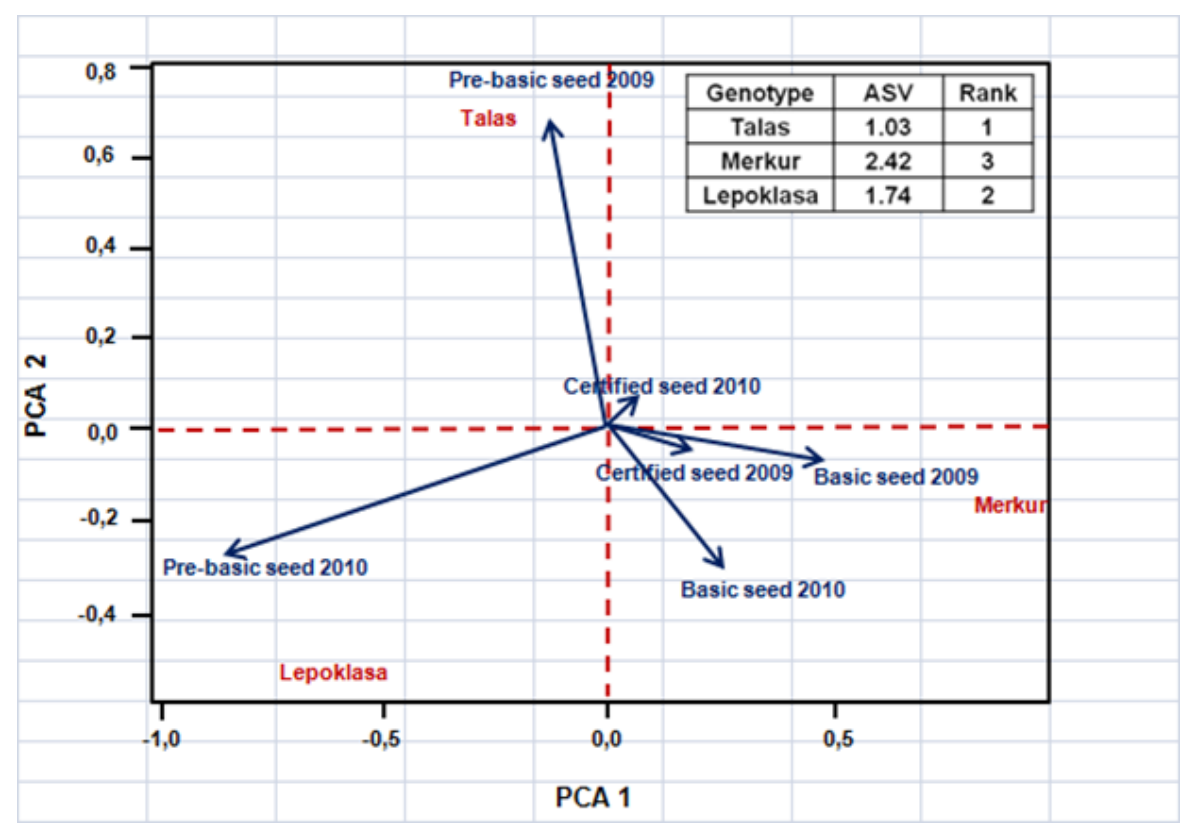

Figure 2. AMMI 2 biplot for the number of spikelets per spike

Table 3. Mutual comparison between the mean values for grain weight per spike and thousand grain weight

\begin{tabular}{|c|c|c|c|}
\hline Factor & Treatment & Grain weight per spike (g) & Thousand grain weight (g) \\
\hline \multirow{4}{*}{ Genotype } & BG Merkur & $2.66 \mathrm{c}$ & $38.63 \mathrm{c}$ \\
\hline & PKB Talas & $2.8 \mathrm{~b}$ & $40.63 \mathrm{~b}$ \\
\hline & \multirow[t]{2}{*}{ PKB Lepoklasa } & $3.18 \mathrm{a}$ & $45.77 \mathrm{a}$ \\
\hline & & $\mathrm{LSD}_{0.01}=0.11 ; \mathrm{LSD}_{0.05}=0.075$ & $\mathrm{LSD}_{0.01}=0.136 ; \mathrm{LSD}_{0.05}=0.102$ \\
\hline \multirow{4}{*}{ Seed category } & Pre-basic seed & $3.92 \mathrm{a}$ & $41.77 \mathrm{a}$ \\
\hline & Basic seed & $2.88 \mathrm{ab}$ & $41.66 \mathrm{~b}$ \\
\hline & \multirow[t]{2}{*}{ Certified seed of first generation } & $2.84 \mathrm{~b}$ & $41.21 \mathrm{c}$ \\
\hline & & $\mathrm{LSD}_{0.01}=0.11 ; \mathrm{LSD}_{0.05}=0.075$ & $\mathrm{LSD}_{0.01}=0.136 ; \mathrm{LSD}_{0.05}=0.102$ \\
\hline \multirow{3}{*}{ Year } & 2009 & $2.73 \mathrm{~b}$ & $40.71 \mathrm{~b}$ \\
\hline & \multirow[t]{2}{*}{2010} & $3.03 \mathrm{a}$ & $42.14 \mathrm{a}$ \\
\hline & & $\mathrm{LSD}_{0.01}=0.077 ; \mathrm{LSD}_{0.05}=0.59$ & $\mathrm{LSD}_{0.01}=0.112 ; \mathrm{LSD}_{0.05}=0.083$ \\
\hline
\end{tabular}

* Different letters within factors indicate statistically significant differences at $5 \%$ statistical level 
Table 4. Analysis of variance of AMMI model for grain weight per spike and thousand grain weight

\begin{tabular}{|c|c|c|c|}
\hline Sources of variation & $\begin{array}{c}\text { Degrees of freedom } \\
(\mathrm{df})\end{array}$ & $\begin{array}{c}\text { Grain weight per spike } \\
\text { (MS) }\end{array}$ & $\begin{array}{l}\text { Thousand grain weight } \\
\text { (MS) }\end{array}$ \\
\hline Treatments (category and year) & 5 & $0.27^{* *}$ & $6.79 * *$ \\
\hline Repetitions & 12 & 0.01 & 1.45 \\
\hline Genotype & 2 & $1.27 * *$ & $212.60^{* *}$ \\
\hline Genotype* Treatment (category and year) $^{*}$ & 10 & $0.06^{* *}$ & 1.55 \\
\hline I PCA 1 & 6 & $0.09 * *$ & 2.29 \\
\hline I PCA 2 & 4 & 0.02 & 0.44 \\
\hline Residue & 17 & 0.01 & 0.99 \\
\hline Error & 24 & 1.60 & 220.95 \\
\hline Total & 80 & 1.62 & 223.38 \\
\hline
\end{tabular}

$* * \mathrm{p}<0.01$

Mollasadeghi et al. (2011) established that grain number per spike, grain weight per spike and thousand grain weight have a direct and positive effect on wheat yield. The highest value was recorded for the genotype PKB Lepoklasa (45.77 g), while the lowest value for the thousand grain weight was recorded for the genotype BG Merkur (38.63 g) (Tab. 3). According to Đurić et al. (2011) for the five genotypes (among them BG Merkur, PKB Talas and PKB Lepoklasa) during five years, the average thousand grain weight was $42.5 \mathrm{~g}$, which is in accordance with the results obtained in this study. Seed category pre-basic seed had a significantly higher value for this trait $(41.77 \mathrm{~g})$ compared to basic seed (41.66 g) and certified seed of the first generation (41.21). In 2010 a significantly higher value $(42.14 \mathrm{~g})$ was recorded compared to 2009 (40.71 g) (Tab. 3).

AMMI model analysis of variance for grain weight per spike established that the interaction was agronomically significant and defined by the first main component (PCA 1) (Tab. 4). Studying the interaction between the genotype and the environment for grain weight per spike, Dimitrijević et al. (2005) reported similar results, where the effect of genotype and interaction also proved to be significant. AMMI model analysis of variance for thousand grain weight showed that the interaction between the factors was not statistically significant, nor was the effect of the main components of the interaction (Tab. 4).

It is visible that among the genotypes analyzed for grain weight per spike, the genotype PKB Talas was closest to zero and that it exhibited the highest stability, while genotypes BG Merkur and PKB Lepoklasa were unstable and exhibited a more pronounced interaction. For seed category, a stable interaction for grain weight per spike is exhibited by the certified seed of first generation in 2010 and pre-basic seed in 2009 (Figure 3).

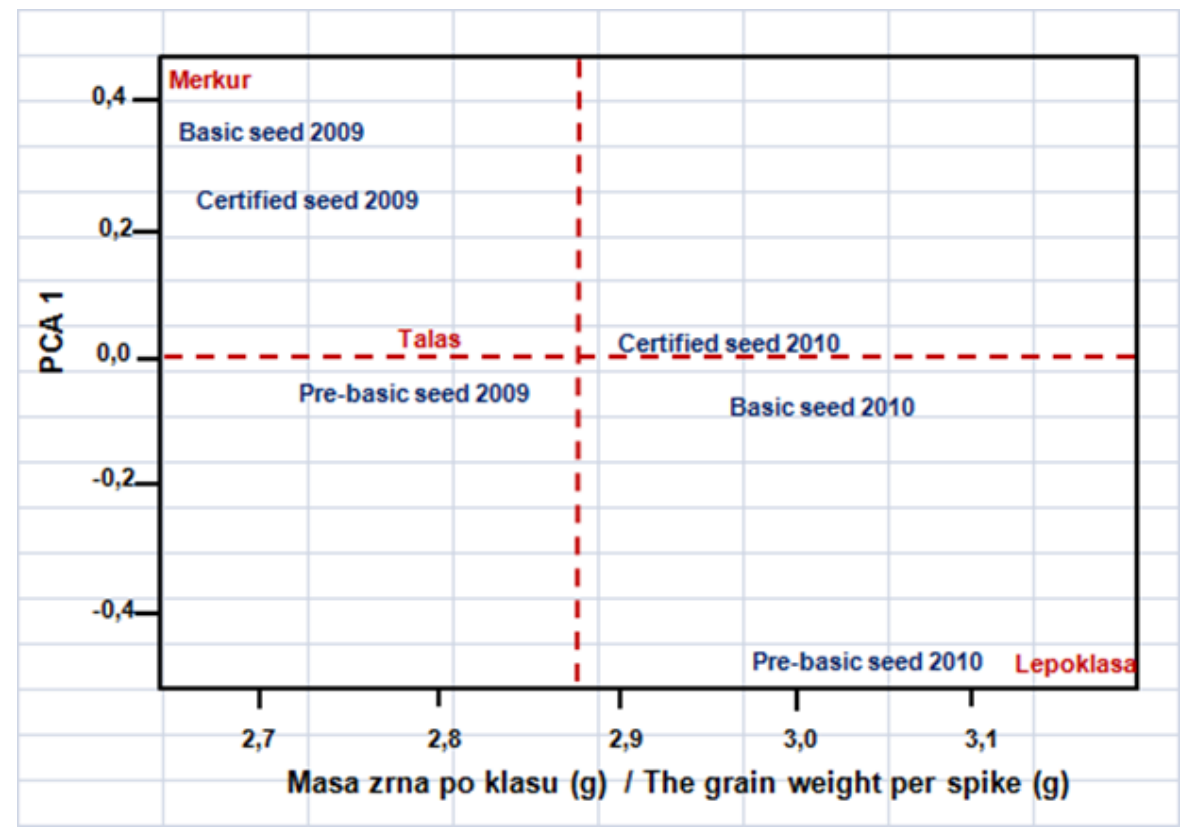

Figure 3. AMMI 1 biplot for the grain weight per spike 
On the AMMI 2 biplot for the grain weight per spike, based on the distance between vectors it can be noted that the genotype PKB Talas, which had the least ASV (0.39), exhibited the highest stability. Genotype PKB Lepoklasa with the highest ASV (2.77), which had the highest average value of grain weight per spike, showed the most instability. Saleem et al. (2015) reported that genotypes which showed yield above the grand mean yield were less stable than genotype which was close to the zero of PCA score with low yield. Mohammed (2009) analyzed 12 different wheat genotypes and stated the best yielding genotype tend to be the most unstable. The vectors for the treatments certified seed of the first generation in 2009 and basic seed in 2009 are the closest, which indicates that they are mutually similar in their reaction to the environment (Figure 4).
Using the AMMI 1 biplot for the thousand grain weight, it was established that the genotype BG Merkur was the most stable, while the other genotypes, as well as the analyzed treatments exhibited relative instability for this trait. Of the investigated treatments, the closest to zero were: seed category basic seed in 2010 and certified seed of first generation in 2009 (Figure 5).

Genotype BG Merkur, which had the least value of thousand grain weight, ranked as the most stable (ASV=2.23). Genotype PKB Lepoklasa, with the highest value of thousand grain weight, was the most unstable (ASV=8.86). Therefore, it can be concluded that it is easier to achieve stability in the less productive genotypes. Treatments with mutually closest vectors were basic seed in 2010 and pre-basic seed in 2010, which indicates that they are similar in their reaction to the environment (Figure 6).

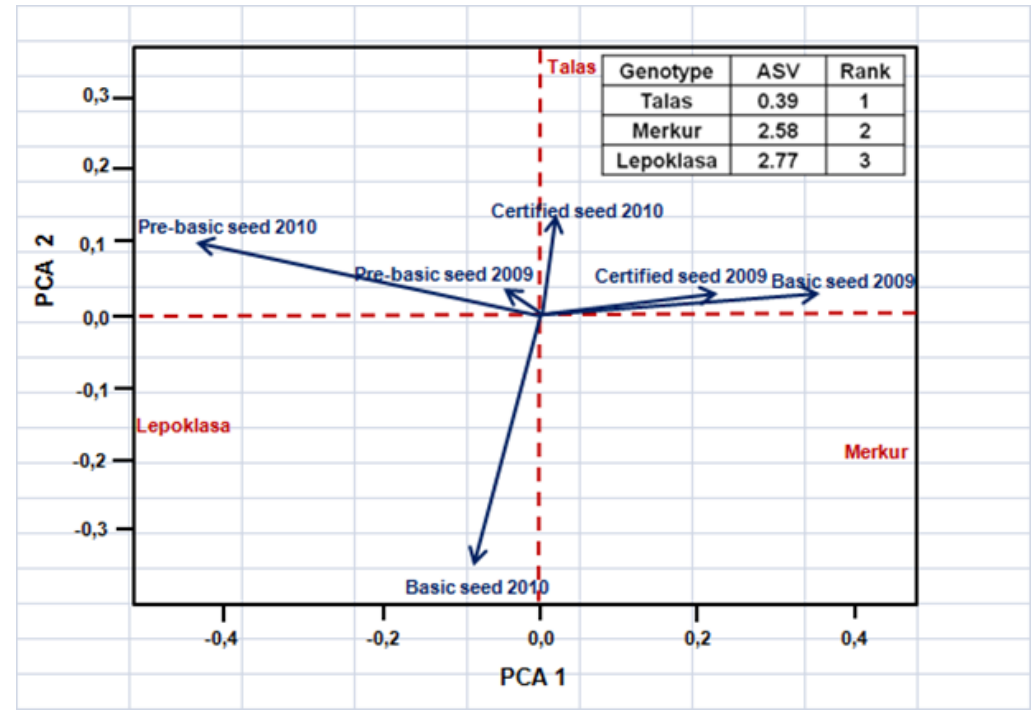

Figure. 4. AMMI 2 biplot for the grain weight per spike

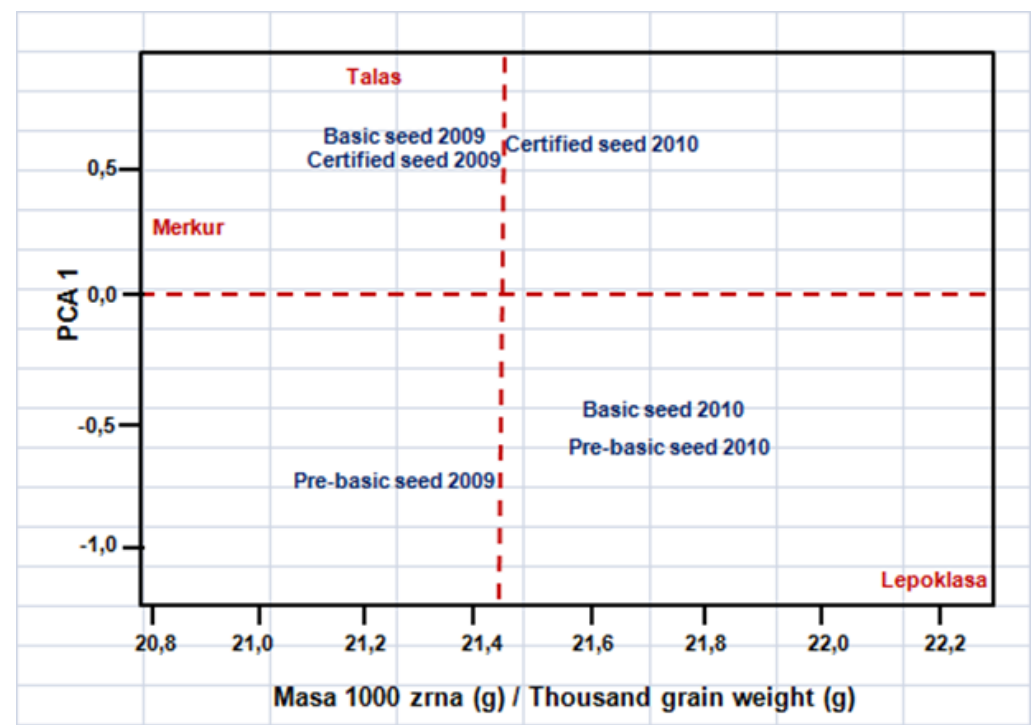

Figure 5. AMMI 1 biplot for thousand grain weight 


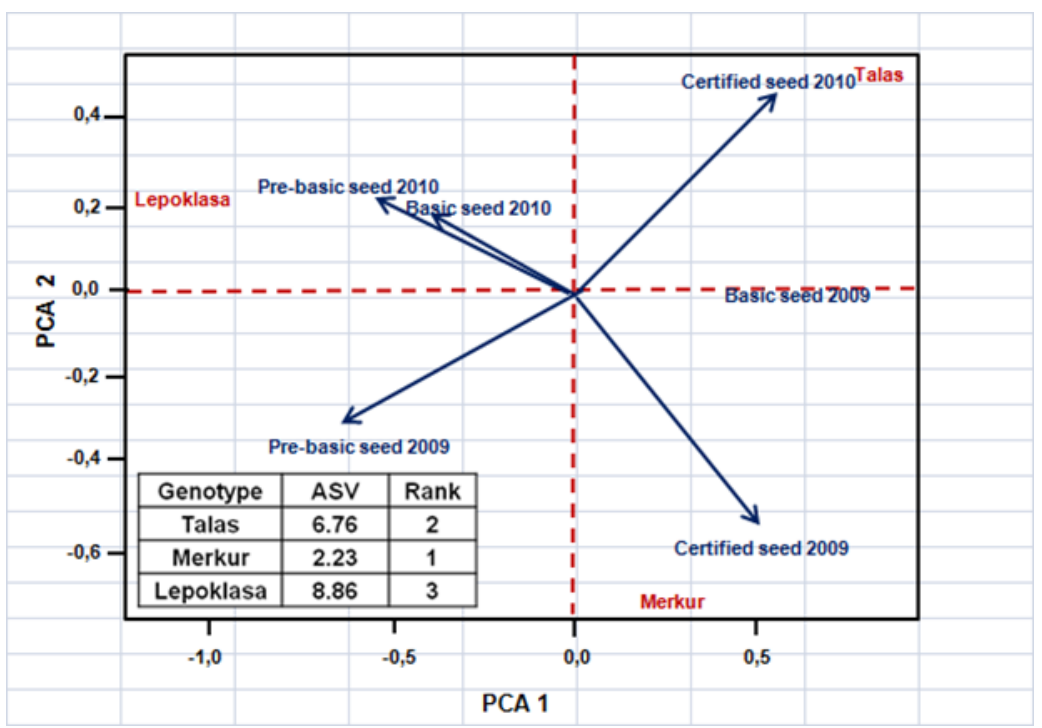

Figure 6. AMMI 2 biplot for the thousand grain weight

\section{Conclusion}

The genotype PKB Lepoklasa achieved the highest values for the largest number of the studied yield components (grain number per spike, grain weight per spike and thousand grain weight), while the genotype BG Merkur had the lowest mean values for all investigated wheat traits. The seed category pre-basic seed had the highest values for all studied traits, while the certified seed of the first generation had the lowest values. All genotypes and seed categories achieved higher values for all analyzed traits in 2010 compared to 2009.

The genotype PKB Talas exhibited the highest stability for the number of spikelets per spike, and grain weight per spike in all seed categories and in both years of experiment. The genotype PKB Lepoklasa exhibited the most instability for the majority of investigated traits. Having in mind that the genotype PKB Lepoklasa does not exhibit stability compared to interactions with seed categories and production year, and possesses the highest values for the largest number of traits, it can be concluded that it is easier to achieve stability using genotypes having lower values for individual traits. Seed categories certified seed of the first generation and basic seed are mutually similar in their reaction to the environment, and this similarity was especially pronounced in 2009 for the traits number of spikelets per spike and grain weight per spike.

\section{References}

Amiri, E., Farshadfar, E., Mahdi, M. \& Jowkar, M. (2013). AMMI analysis of wheat substitution lines for detecting genes controlling adaptability. International Journal of Advanced Biological and Biomedical Research, 1(9), 1112-1123.
Aycecik, M., \& Yildirim, T. (2006). Path coefficient analysis of yield and yield components in bread wheat (Triticum aestivum L.) genotypes. Pakistan Journal of Botany, 38(2), 417-424.

Bilgin, O., Kayihan, Z., Korkut, Z., K., Baser, I., Daglioglu, O., Ozturk, I., Kahraman, T., \& Balkan, A. (2011). Genetic variation and inter-relationship of some morpho-physiological traits in durum wheat (Triticum durum (L.) Desf.). Pakistan Journal of Botany, 43(1), 253-260.

Dimitrijević, M., Knežević, D., Petrović, S., Zečević, V., Bošković, J., Belić, B., \& Banjac, B. (2011). Stability of yield components in wheat (Triticum aestivum L.). Genetika, 43(1), 29-39.

Dimitrijević, M., \& Petrović, S. (2005). Genetika populacije - adaptabilnost $i$ stabilnost genotipa. Poljoprivredni fakultet, Novi Sad i Naučni institute za ratarstvo i povrtarstvo, Novi Sad.

Dimitrijević, M., Petrović, S., Belić, M., Hadžić, V., Kraljvić-Balalić, M., Nešić, Lj., Kapor, Z., Beljanski, N., \& Vuković, N. (2005). Genetička varijabilnost sorti pšenice na solonjecu u uslovima popravke zemljišta. Letopis naučnih radova Poljoprivrednog fakulteta, 29(1), 100-112

Đurić, N., Obradović, S., Trkulja, V., \& Martić, M. (2011). Analiza kvaliteta semena PKB sorti ozime pšenice dorađenih u periodu 2005-2010. godine. Zbornik naucnih radova Instituta PKB Agroekonomik, 17(1-2), 13-16.

Farshadfar, E., Mahmodi, N., \& Yaghotipoor, A. (2011). AMMI stability value and simultaneous estimation of yield and yield stability in bread wheat (Triticum aestivum L.). Australian Journal of Crop Science, 5(13), 1837-1844.

Gauch, G. H., \& Zobel, R. W. (1997). Interpreting megaenvironments and targeting genotypes. Crop Science, 37, 311-326.

Golparvar, R. A. (2014). Genetic control and heredity of harvest index and biological yield in bread wheat (Triticum aestivum L.). Genetika, 46(1), 43-48.

Hagos, G. H., \& Abay, F. (2013). AMMI and GGE biplot analysis of bread wheat genotypes in the northern part of Ethiopia. Journal of Plant Breeding and Genetics, 1, 12-18.

Hamlabad, B. H. (2012). Yield stability of promising lines of winter and facultative wheat in different climate of Iran. African Journal of Agricultural Research, 7(15), 2304-2311.

Hintsa, G., Abraha, H. M., Tesfay, B. (2011). Genotype by Environment interaction and grain yield stability of early maturing bread wheat (Triticum aestivum L.) genotypes in the drought prone areas of Tigray region, Northern Ethiopia. Ethiopian Journal of Applied Science and Technology, 1(2), 3-7.

Hristov, N., Mladenov, N., Kondić-Špika, A., Marjanović-Jeromela, A., Jocković, B., \& Jaćimović, G. (2011). Effect of 
environmental and genetic factors on the correlation and stability of grain yield components in wheat. Info Genetika-Belgrade, 43(1), 141-152.

Knežević, D., Zećević, V., Stamenković, S., Atanasijević, S., \& Milošević, B. (2012). Variability of number of kernels per spike in wheat cultivars (Triticum aestivum L.). Journal of Central European Agriculture, 13(3), 617-623.

Mladenov, N., Denčić, S., Hristov, N., \& Kobiljski, B. (2005). Značaj sorte za unapređenje proizvodnje pšenice u Republici Srbiji. Zbornike radova Instituta za ratarstvo i pourtarstvo, 41, 11-19.

Mohammed, M. I. (2009). Genotype x Environment interaction in bread wheat in Northern Sudan using AMMI analysis. AmericanEurasian Journal of Agricultural and Environment Sciences, 6(4), $427-$ 433.

Mollasadeghi, V., Imani, A. A., Shahryari, R., \& Khayatnezhad, M (2011). Correlation and path analysis of morphological traits in different wheat genotypes under end drought stress condition. Middle-East Journal of Scientific Research, 7(2), 221-224.

Motamedi, M., Safari, P., \& Mohammadi, G. (2013). Additive main effect and multiplication interaction analysis of grain yield in bread wheat genotypes across environments. International Journal of Biosciences, 3(8), 218-225.

Rad, M. R. N., Kadir, M. A, Rafii, M. Y., Jaafar, Z. E. H., Naghavi, M. R., Ahmadi, F. (2013). Genotype $\times$ environment interaction by AMMI and GGE biplot analysis in three consecutive generations of wheat (Triticum aestivum) under normal and drought stress conditions. Australian Journal of Crop Science, 7(7), 956-961.
Perišić, V., Milovanović, M., Staletić, M., \& Đekić, V. (2011). Nasleđivanje dužine klasa i broja zrna u klasu kod hibrida pšenice. Zbornik naučnih radova Instituta PKB Agroekonomik, 17(1-2), 19-26.

Petrović, S., Dimitrijević, M., Ljubičić, N., \& Banjac, B. (2013). Nasleđivanje osobina klasa heksaploidne pšenice (Triticum aestivum L.). Selekecija i semenarstvo, 19(1), 43-52.

Purchase, J. L., Hatting, H., \& Van Denventer, C. S. (2000). Genotype by environments interaction of wheat in South Africa: stability analysis of yield performance. South Africa Journal of Plant Science, 17(3), 101-107.

R Development Core Team. (2015). A language and environment for statistical computing. R Foundation for Statistical Computing, Viena, Austria. Retrieved from http://www.R-project.org

Roostaei, M., Mohammadi, R., \& Amri, A. (2014). Rank correlation among different statistical models in ranking of winter wheat genotypes. Crop Journal, 2, 154-163.

Saleem, N., Ahmad, M., Vashnavi, R., Bukhari, A., Dar, Z. A. (2015). Stability analysis in wheat: An application of additive main effects and multiplicative interaction. African Journal of Agricultural Research, 10(4), 295-300.

Zečević, V., Knežević, D., \& Mićanović, D. (2004). Genetic correlations and path coefficient analysis of yield and quality components in wheat. Genetika, 36(1), 13-21.

Zobel, R.W., Wright, M.J., Gauch, H.G. (1988). Statistical analysis of a yield trial. Agronomy Journal, 80, 388-393.

\section{Analiza glavnih aditivnih efekata i multiplikativne interakcije komponenti prinosa pojedinih genotipova pšenice}

\section{Nenad Đurić · Mirela Matković · Gorica Cvijanović · Gordana Dozet}

Sažetak: U toku dvogodišnjeg istraživanja izvedeno je ispitivanje uticaja genotipa, kategorije semena i godine na komponente prinosa (broj klasića po klasu, broj zrna po klasu, masa zrna po klasu i masa 1000 zrna) kod tri genotipa pšenice. Genotip PKB Lepoklasa i kategorija semena predosnovno seme su ostvarili najviše vrednosti za najveći broj ispitivanih svojstava, dok su genotip BG Merkur i sertifikovano seme prve generacije ostvarili najniže vrednosti. Više vrednosti ispitivanih osobina su ostvarene u 2010. u odnosu na 2009. godinu. AMMI analizom je ustanovljen značajan uticaj interakcije faktora i glavnih komponenata (PCA 1 i PCA 2) kod svih ispitivanih svojstava, osim kod mase 1000 zrna. Genotip PKB Talas je ispoljio najveću stabilnost, dok je genotip PKB Lepoklasa pokazao najveću nestabilnost. Kategorije semena sertifikovano seme prve generacije i osnovno seme su međusobno slične po reakciji na interakciju faktora.

Ključne reči: AMMI analiza, genotipovi, komponente prinosa, PCA, pšenica, seme 